Further information on future developments is given in No. 17 of The B.B.C. Record (Fobruary 1963), which emphasizes the value of the two television servicos. Moroover, it outlines the first year's proposals for adult education in television, and in the Sixth Bishop Boll Momorial Lecturo, "Future Prospects in Broadcasting", delivered by $\mathrm{H}$. Carleton Greene, the director-general of the Corporation, on $\Lambda$ pril 30, and now published as a pamphlet; Mr. Greene strosses the complementary functions of the Corporation and the importance of concerning itself with the whole of the national lifo, with mass inter- ests and with minority intorests. He suggests that if broadcasting planners do their jobs properly they can croate and stimulate cultural and oducational demands as woll as moet thom. Ho directs attontion to the use of television programmes in teaching and to the introduction of experimontal programmes for uso in technical colleges and colleges of further education. Furthormore, ho urges that it would not be right to make an educational channel a chargo on licence revenue: it should receive a soparate grant-in-aid, as do the Extornal Sorvices.

\title{
SOILS AND LAND USE IN NORTH WALES
}

\begin{abstract}
A SURVEY of the soils of North Wales was started by the late Prof. G.W. Robinson and his colloagues, who published sovoral roports and maps in tho Welsh Journal of Agriculture. The work has been completed recently with a momoir, and accompanying maps, which covors an area of 240 sq. milos, strotching from Pentraeth, in Eastern Anglesey, and Llandudno in the north to Waenfawr and Bettws-y-Cood in the south*. The Conway valloy and most of the high land of Snowdonia are included.

The climate is maritime and its most important influence in soil development is the rainfall, which incroasos stoeply from somo $30 \mathrm{in}$. on the coast to $120 \mathrm{in}$. on the mountains in the south. The parent materials of the soils includo acid and basic igneous rocks, schist and shale and their derived drifts, non-calcareous clay and limostone, peat and various mixed drifts from igneous and sedimontary rocks. The soil mapping and classification follow the custom of the Soil Survey and profile description includes information on site, drainage, parent matorial, horizons, colour, texture and structure. Soils of five major soil groups have been recognized, namely, brown earths, calcaroous, gloy, podzolized and organic soils, but there is also a considerable area of immature soils occurring on youthful sands and alluvium. Each is described and sub-divided into sub-groups and soil sorios, and again * Agricultural Rescarch Council. Memoirs of the Soil Survey of Great Britain-England and Wales. The Soils and 1 and IIse of the District Aroun plates. (London: II.M.S.O., 1063.) 358 . net.
\end{abstract}

groupod into lowland, marginal and mountain soil zonos.

The larger part of the memoir is naturally taken up with detailod doscriptions of the soil serios and with appendixes on particular profilos and analytical data, but thoro is a chapter on land use, compiled with the assistance of G. Edwards, H. F. Roborts and W. A. Lindsay-Smith. This opens with a historical review of the area from the time of the disappoaranco of the valloy glaciers, with inferencos to be drawn from studios on pollen grains and dating by radioactive carbon, on changes in climate, flora and human settlement. Rocont agricultural statistics show the variation in size of holdings and the changes in crops and livestock between 1935 and 1955. An interesting aspect is the continuous rise in sheep production, but there has also been a pattern of technical improvomont and change in farm economy to meet the seasonal fluctuations in domand. This is diseussed in relation to the five regions of the area. There are about 12,000 acres of woodland, about half planted by the Forestry Commissionlargely conifer high forest. Many factors, of course, determine tree growth, but it seems clear that goo * oak and olm are to be found on froely drained slopes of soils dorived from mixed drift although falling short of conifers in yiold production.

Numorous figures and tables are of great assistance in assimilating the information presented, and soveral excellent photographs illustrate the outstanding features of the area in question.
A. M. Sмiтh

\section{COMPARATIVE BIOCHEMISTRY OF THE LEGUMINOSAE}

\begin{abstract}
A SYMPOSIUM on "The Comparative Biochemistry of the Leguminosae", organized by the Plant Phenolics Group, was hold at the John Innes Instituto, Bayfordbury, Hortford, during September 10-11. Tho aim of the meeting was to bring togethor workers in diverse scientific fields but sharing a common interest in this group of plants. Tho Leguminosae, which contains some 550 genera and 12,000 species, is, in economic importance, second only to the Graminewe, and mombers of the family contain a romarkably large number of interesting and unusual chemical constituents. In his opening papor, N. W. Simmonds (John Innes Institute) reviowed tho systomaties of the family and summarized the many uses legumes are put to as foods, forages, timbers, gums, resins and tannins. Dr. R. Cooper (Rothamsted Exporimontal Station), in dealing with root nodulation, pointed out that 90 per cont of the fixed nitrogen in the world had come from leguminous root nodules. His reviow of tho conditions required for successful nodulation by Rhizobium showed that many factors, including the occurrence of the correct host-symbiont specificities and the presonce of the right kind of polysaccharide in the host roots, were involved.
\end{abstract}

Chemistry may well be, in the future, of considerable value to the systernatists dealing with legunnes. Its present contribution is slight, mainly because very fow taxa have been thoroughly surveyed chemically. Dr. R. E. Alston and his colleagues in the University of Texas are therofore concentrating their efforts on a singlo gonus, Baptisia. Dr. Alston illustrated his talk on this genus with pictures of the phenolie spots obtained on two dimonsional chromatograms of leaf and flower extracts. The patterns so obtained can be used not only to distinguish most of the eighteon or so species but also muny of tho intorspocific hybrids. Compounds which, at the moment, show more promise as taxonomic markers than the phenols are the free amino-aoids. Besides having the common protoin amino-acids, legume seeds contain a range of unusual ninhydrin positive substances, such as canavanino, homoarginino, $\gamma$-hydroxyhornoarginine and lathyrine. Dr. A. F. Bell (King's College, Tondon), in the next paper, showed that most species of Lathyrus could bo divided into four groups, depending on their characteristic amino-acid patterns; species of Vicia could be divided in a similar manner. 